\title{
Author Correction: Single-cell analysis of EphA clustering phenotypes to probe cancer cell heterogeneity
}

Andrea Ravasio, Myint Z. Myaing, Shumei Chia, Aditya Arora, Aneesh Sathe, Elaine Yiqun Cao, Cristina Bertocchi (1D, Ankur Sharma (1), Bakya Arasi, Vin Yee Chung (D, Adrienne C. Greene, Tuan Zea Tan (1), Zhongwen Chen (1D, Hui Ting Ong, N. Gopalakrishna lyer, Ruby YunJu Huang, Ramanuj DasGupta (D), Jay T. Groves \& Virgile Viasnoff(D)

Correction to: Communications Biology https://doi.org/10.1038/s42003-020-01136-4, published online 6 August 2020.

In the original published version of the Article, contributing author Adrienne C. Greene of the University of California, Berkeley was incorrectly listed as Adrianne C. Green of the National Cancer Centre Singapore. The error has been corrected in the HTML and PDF versions of the Article.

Published online: 06 November 2020

\footnotetext{
(c) (i) Open Access This article is licensed under a Creative Commons Attribution 4.0 International License, which permits use, sharing, adaptation, distribution and reproduction in any medium or format, as long as you give appropriate credit to the original author(s) and the source, provide a link to the Creative Commons license, and indicate if changes were made. The images or other third party material in this article are included in the article's Creative Commons license, unless indicated otherwise in a credit line to the material. If material is not included in the article's Creative Commons license and your intended use is not permitted by statutory regulation or exceeds the permitted use, you will need to obtain permission directly from the copyright holder. To view a copy of this license, visit http://creativecommons.org/licenses/by/4.0/.
}

(C) The Author(s) 2020 